\title{
ATTEMPT TO RECLAIM WITH CHEMICALS A SALTY CLAY IN PUERTO RICO ${ }^{1}$
}

\author{
J. A. Bonnet, P. Tirado Sulsona and M. A. Lugo López 2 \\ INTRODUCTION
}

Lajas valley is located in the dry southwestern area of Puerto Rico where the mean annual rainfall is 31.35 inches. Recent records obtained in an open pan surface, from February to July 1949 inclusive, indicate that the monthly evaporation there varies between six and eight inches. An irrigation project for that area is now under construction by the Insular Government. Field and laboratory work reported previously by Bonnet $(1,2)$ indicate that this area includes 25,000 acres of good land fit for irrigation, 5,500 acres of salty land that may be reclaimed by washing with fresh water, and 5,000 acres of high salty land that require reclamation with chemicals.

The infiltration rate of the salty area as determined in the field by the method of Nelson \& Muckenhirn (4), during the eighth-hour run was slow, i.e. between .03 and .08 inch of water.

This paper reports the results obtained in a field experiment done in that high salty land when sulphur and gypsum were added for reclamation purposes. The yields of two consecutive crops of rice and sugar cane and the specific conductance values of $1: 2$ soil-water suspensions were used as yardsticks to measure the effect of the chemical used for reclamation.

\section{EXPERIMENTAL}

The rice crop - A tract of high salty Aguirre clay was chosen in Lajas valley for the field test. Twenty square plots, each $20^{\prime} \times 20^{\prime}$, were placed in three rows; the first and second with eight plots each and the third with four plots. The rows and plots were separated by a ditch 2-feet wide followed by a pathway 5 -foot wide and a second ditch. $\bullet$ Ditches were placed conveniently to allow for the individual irrigation and drainage of each plot. The plots were grouped into five blocks, and each block was subdivided into four plots for the following randomized treatments:

\footnotetext{
1 Contribution from Soils Department, Agricultural Experiment Station, University of Puerto Rico, Río Piedras, Puerto Rico.

2 Head Soils Department, Assistant Soil Conservationist, and Assistant Soil Technologist, respectively.
} 
1. Check

2. Leached

3. Sulphur added to the soil at the rate of 218 pounds per acre.

4. Gypsum added to the soil at the rate of 436 pounds per acre.

The sulphur and gypsum were brought to the fields in ground form as milled respectively, by a cement factory and a superphosphate plant in Puerto Rico. . The large pieces were smashed on the ground. The chemicals were hoed and mixed well with the surface soil. Each plot was converted into a basin for growing rice under irrigation at a water level of about four inches. This was done by piling surface soil from the adjacent ditches and pathway forming an earth mound around the plot's perimeter (see photo).

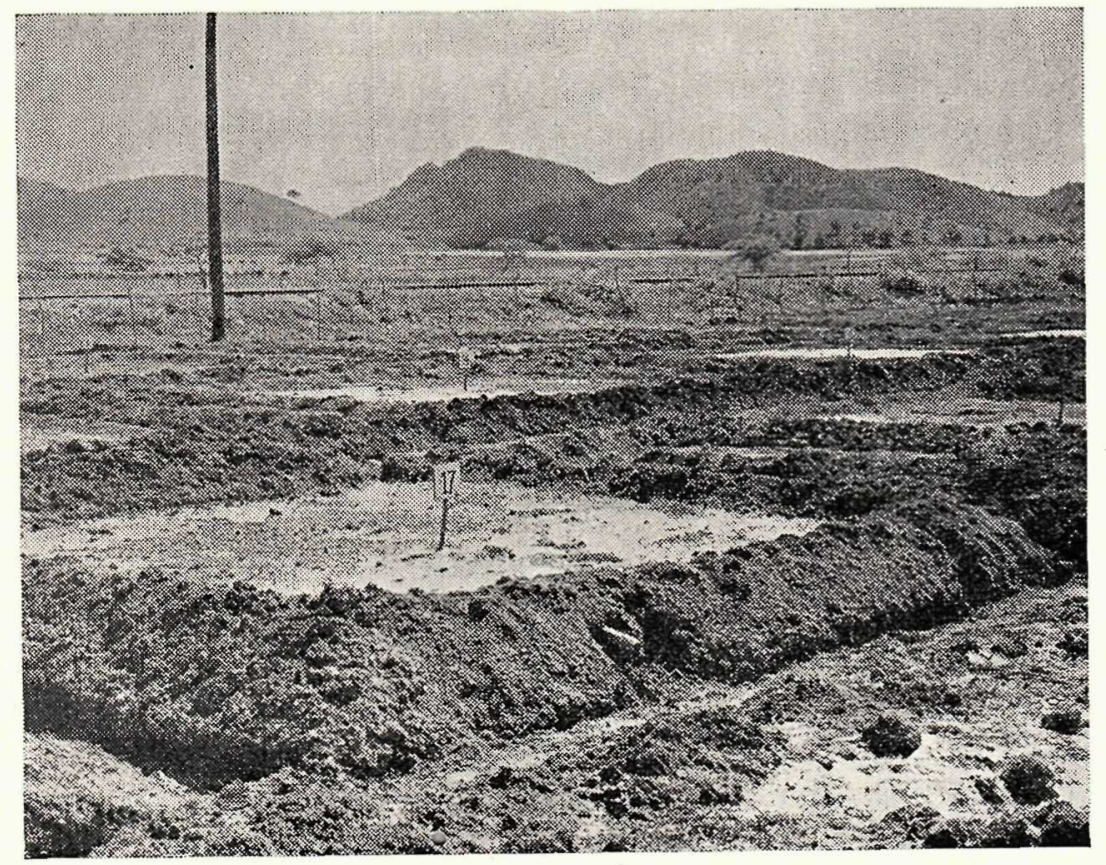

\section{PHOTO OF FIELD TEST IN HIGH SALTY AGUIRRE CLAY IN ILAJAS VALLEY}

Plots ready for planting rice under continuous irrigation. Inlet water pipe at upper corner of plot. Pipes were removed the second week. Then the basin-type of irrigation was used. Observe ditch, pathway and ditch dividing the plots. Plots 14 and 15 belong to the second row, 17 is the extreme left plot of the four last plots in the third row. 
Preliminary washings of soluble salts with irrigation water were given to all treatments except the check. The corresponding plots were flooded early in the morning and kept flooded during working days. The water supply was that from Río Loco, the same irrigation source used successfully for many years in the surrounding good fields of sugar cane.

After the preliminary washings, an inlet and an outlet pipe were placed at convenient heights, in each plot, for the continuous flow of irrigation water for the rice crop.

Ammonium sulphate at the rate of 200 pounds per acre was added to each plot, one day previous to planting. Seeds of rice, Fortuna variety, were broadcast on September 10, 1947 at the rate of four pounds per plot. The germination capacity of the seed was found in the laboratory to be about 70 per cent. The seed was soaked in water the night before planting but was slightly dried out a few hours before planting. Water was run continuously except in non-working hours. After the first week, due to chlorosis in the plants, the system of continuous irrigation flow was abandoned. The plots were then kept wet at all times, by flooding every morning until two weeks before harvest when the water was removed. The crop was harvested on December 10, 1947 at the age of three months.

The sugar cane crop-The same plots and treatments for the rice test were used for sugar cane but with the furrow irrigation system. The corresponding earth mounds were raked into each plot and the surface soil was then leveled. Sulphur and gypsum were applied at the rate of one and two tons per acre, respectively. Four furrows at 5 -foot distance were dug in each plot.

The field was planted on January 19, 1948 with cane variety POJ 2878. Three-eyed pieces, one-foot apart, were planted in a row on top of the narrow bank between the furrows. Each plot contained five rows of cane. The field was immediately irrigated by filling the furrows to the top with irrigation water. The water was kept in the furrow by plugging its end with earth. The frequency period of irrigation varied between 8 and 10 days until one-month previous to harvest when no more irrigation water was used.

The crop was fertilized two times: the first, on March 4, 1949 about six weeks after planting; and the second, on May 5, 1949 about nine weeks later. The fertilizer used was only 
ammonium nitrate at the rate of 4 pounds per plot in each application or 871 pounds per acre. This corresponds to a total application of 283 pounds of nitrogen $(\mathrm{N})$ per acre based on a guarantee value of $32.5 \% \mathrm{~N}$ in the fertilizer bag.

The crop was harvested on February 1, 1949 at the age of $121 / 2$ months. The juice from ten canes selected at random from each plot was expressed out in the Experiment Station's mill. Determinations for sugar content, $\mathrm{pH}$, and specific conductance were run in the cane juices.

After the cane crop was harvested, samples were taken from each plot, of soil layers nine-inch deep down to three-feet, for $\mathrm{pH}$ and specific conductance determinations.

\section{OBSERVATIONS AND FIELD DATA}

Rice crop-The first week after the rice was planted, an algae-soil crust and the rice seedlings were brought up to the water surface in six plots, including one check, one leached, two sulphur, and two gypsum treatments. Algae growth was also noticeable in the other plots and a general chlorosis sympton developed in the seedlings of the whole field. It was found necessary, as mentioned before, to stop the continuous irrigation flow and proceed with the basin type of irrigation.

The rice plants continued growing fairly well but those in the center of all plots, where the water collected, had a yellowish green color. The rest of the crop was green and more vigorous. The northern half of the plot was better than the southern half. This was due to wind effect blowing from the South.

In two check plots that were not irrigated for three consecutive days, the soil cracked and hardened and the plants began to be affected. They recovered after being irrigated.

A worm attack, possibly Laphygma frugiperda, appeared in the fifth week. The worms fed on the leaves and stems of the rice plants. Three sprayings with a solution of $2 \frac{1}{2}$ pounds of lead arsenate in 50 gallons of water were succesful in checking the infection.

Some of the rice plants began heading seven weeks after planting. At this time, growth was still poorer in the center of all plots. 
The mean yields of the whole plant and the seed rice are given in table 1 .

TABLE 1.-MEAN YIELD OF FORTUNA RICE, NINETY DAYS OLD, GROWN IN SALTY AGUIRRE CLAY UNDER IRRIGATION IN LAJAS VALLEY

\begin{tabular}{|c|c|c|c|}
\hline Number & Treatment & $\begin{array}{l}\text { Whole } \\
\text { tlant }\end{array}$ & Seed Rice \\
\hline & & Lbs./A & Lbs./A \\
\hline $1 \ldots \ldots \ldots$ & 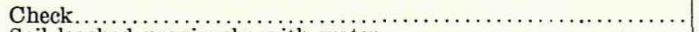 & 4,361 & 996 \\
\hline $2 \ldots \ldots \ldots \ldots$ & 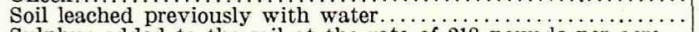 & 4,160 & 953 \\
\hline $3 \ldots \ldots \ldots \ldots$ & Sulphur added to the soil at the rate of 218 pounds per acre... & 4,165 & 898 \\
\hline $4 \ldots \ldots \ldots \ldots$ & Gypsum added to the soil at the rate of 436 pounds per acre... & 4,254 & 828 \\
\hline
\end{tabular}

No significant difference was found between the mean yields of seed rice of the four treatments.

The Sugar Cane Crop-The mean cane yields, in tonnage and sugar per acre for each of the four treatments are given in table 2.

\begin{tabular}{|c|c|c|c|}
\hline Number & Treatment & $\begin{array}{c}\text { Tons Cane } \\
\text { per Acre }\end{array}$ & $\begin{array}{c}\text { Tons Sugar } \\
\text { per Acre }\end{array}$ \\
\hline | & 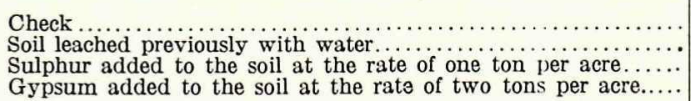 & $\begin{array}{l}19.28 \\
14.73 \\
17.41 \\
22.68\end{array}$ & $\begin{array}{l}1.667 \\
1.196 \\
1.428 \\
2.022\end{array}$ \\
\hline
\end{tabular}

No significant difference was found between the means of tons of cane or tons of sugar per acre of the four treatments.

The mean values of specific conductance, soluble salts and $\mathrm{pH}$ for the cane juices from each of the four treatments are reported in table 3 . The soluble salts were estimated by multiplying the specific conductance by seven.

TABLE 3.-MEAN VALUES OF SPECIFIC CONDUCTANCES, SOLUBLE SALTS AND pH OF SUGAR CANE JUICES OF POJ 2878 CANE HARVESTED AT THE AGE OF $12^{1 / 2}$ MONTHS IN SALTY AGUIRRE CLAY OF LAJAS VALLEY

\begin{tabular}{|c|c|c|c|c|}
\hline Number & Treatment & $\begin{array}{c}\text { Specific } \\
\text { Conductance* }\end{array}$ & $\begin{array}{l}\text { Estimated } \\
\text { Soluble } \\
\text { Salts }\end{array}$ & $\mathrm{pH}$ \\
\hline $\begin{array}{l}1 \ldots \ldots \\
2 \ldots \ldots \\
3 \ldots \ldots \\
4 \ldots \ldots \\
\ldots \ldots\end{array}$ & 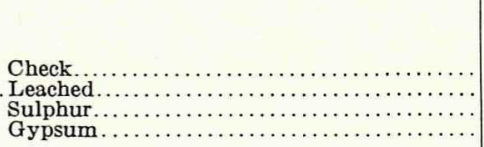 & $\begin{array}{l}687 \\
750 \\
655 \\
695\end{array}$ & $\begin{array}{c}\text { p. p. m. } \\
4,809 \\
5,250 \\
4,585 \\
4,865\end{array}$ & $\begin{array}{l}5.72 \\
5.69 \\
5.72 \\
5.69\end{array}$ \\
\hline
\end{tabular}

* mhos. $\times 10^{-5}$ at $25^{\circ} \mathrm{C}$. 
The mean specific conductances for soil samples taken from each of the four treatments at 9-inch layers down to a depth of 36 inches and their mean $\mathrm{pH}$ are given in table 4 . The specific conductances were determined in 1-2 soil water suspensions shaken in an agitator for 30 minutes.

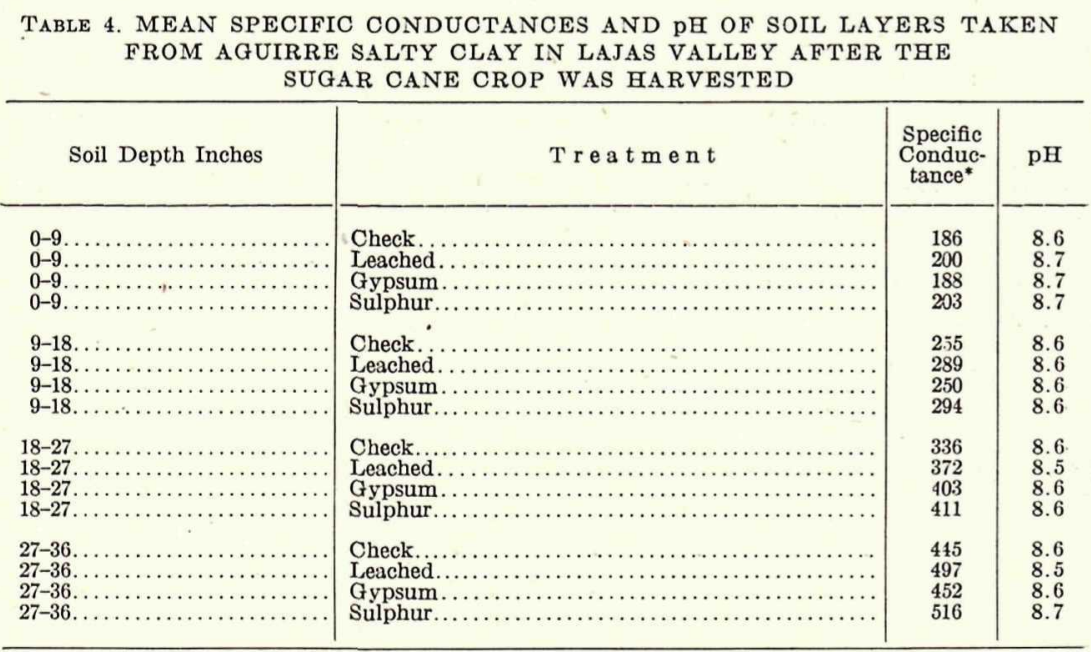

* mhos $\times 10^{-5}$ at $25^{\circ} \mathrm{C}$. of a $1: 2$ soil-water suspension.

\section{CHEMICAL ANALYSES OF WATER SUPPLIES}

The waters from Río Loco have been used successfully for irrigation in the surrounding sugar cane fields. The chemical analyses of its waters, under normal flow and in flood are reported in table 5. They are also reported for the potential water sources to be used for irrigation of Lajas valley when the project is established.

\section{DISCUSSION}

The amount of rice imported (3) in Puerto Rico during fiscal year 1947-1948 was 265,724,074 pounds with a total value of $\$ 28,586,575$. The production of rice in Puerto Rico for that same fiscal year was $14,800,000$ pounds in 25,535 acres with a yield of 580 pounds per acre. That yield is for unfertilized upland rice since in Puerto Rico the growth of paddy rice is limited to a few acres.

The mean yield of all four treatments obtained for a threemonth fall crop of paddy rice, Fortuna variety, fertilized at the rate of 200 pounds of ammonium sulphate per acre in salty Agui- 


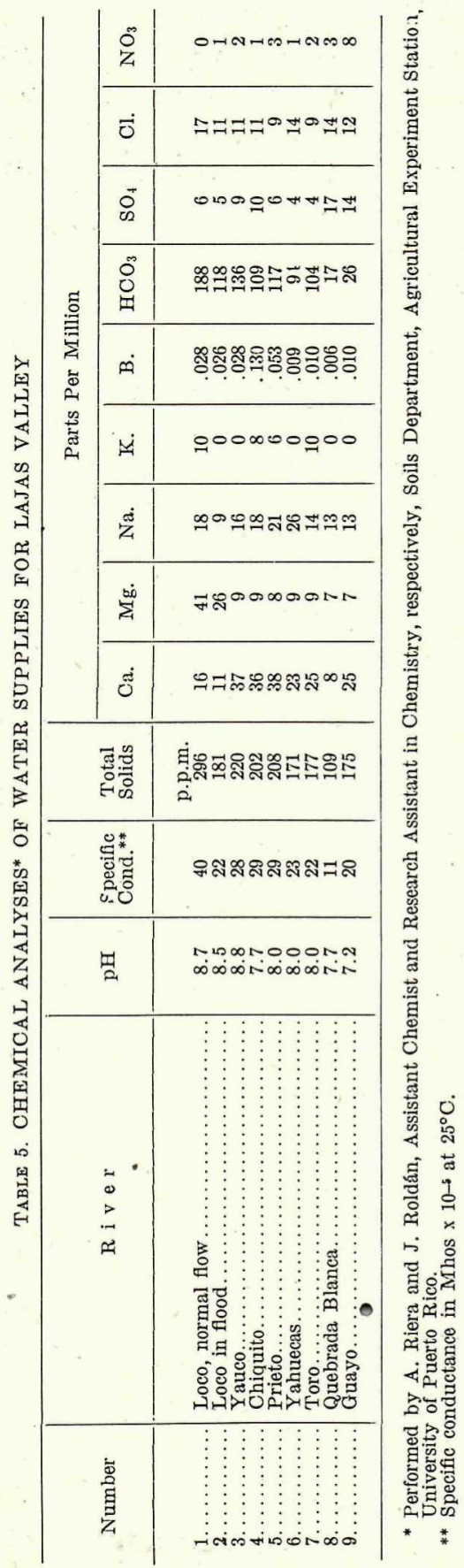


rre clay (table 1) was 919 pounds of seed rice per acre. Deducting 35 percent for the hull's weight, this mean yield corresponds to 597 pounds of rice per acre which corresponds to its yield when grown as upland rice. The chlorotic symptoms of the Fortuna rice variety grown in Lajas valley indicated that it was not suitable as a paddy variety. Research with other suitable rice varieties is needed to know about the potentialities of the highly salty clay lands in Lajas valley for production of paddy rice.

Dr. Jenkin W. Jones, Principal Agronomist in charge Rice Investigations, U. S. D. A. commented as follows: "I do not know of course why Fortuna did not do well under such conditions. Fortuna is grown here under irrigation and is a reasonably productive variety. Of all of our lowland varieties, Fortuna apparently does produce better yields than the others when grown under upland conditions. The proportion of grain to whole plant, in your experiment is quite low, and apparently some factor other than the salinity of the soil might be responsible for the comparatively low yields and similarity in the results from all treatments. Usually, the Fortuna variety requires from 140 to 155 days to mature in Louisiana; hence, the low yields you obtained indicate that conditions in Puerto Rico are very different from those in our Gulf Coast area." The age at maturity of the fall crop of Fortuna rice, harvested in salty Aguirre clay, was 90 days. The mean ratio of whole plant to seed rice, for all treatments, was 4.6 (table 1).

The light applications of sulphur and gypsum of 218 and 436 pounds per acre, respectively, were not effective in increasing significantly (table 1) the yield of the rice crop. The heavier application of one and two tons per acre of sulphur and gypsum, respectively, were not either effective in increasing significantly (table 2) the tonnage and sugar content of POJ 2878 cane.

The cost of sulphur and gypsum for reclamation purposes in Puerto Rico is too high. For the ton of sulphur used $(99.5 \% \mathrm{~S})$ the quotation on February 24, 1947 f.o.b. factory was $\$ 42$. The cost of the gypsum $\left(78.80 \% \mathrm{CaSO}_{4}\right)$ f.o.b. in the field was $\$ 38$.

The cane juices from all treatments were salty, but were acid in reaction, around $\mathrm{pH} 5.7$ (table 3). The mean specific conductance for the treatments was found to be 697 mhos $\times 10^{-5}$ at $25^{\circ} \mathrm{C}$ equivalent to an estimated amount of 4879 parts per 
million of soluble salts. Juices of 20 canes from non-salty soils gave specific conductances ranging from 130 to 275 mhos $\times 10^{-5}$ at $25^{\circ} \mathrm{C}$ equivalent to about 910 and 1925 parts per million of soluble salts, respectively. These good juices are slightly less acid, $\mathrm{pH} 5.8$ to 6.0 , than the ones from POJ 2878 cane grown in the highly salty land.

All the plots, irrespective to treatments, were alkaline $(\mathrm{pH}$ 8.5 to 8.7) in the 3-foot soil profile, after the cane crop was harvested (table 4). The specific conductances of the four 9 -inch soil layers were also very high. They increased with depth from a mean of 194 mhos $\times 10^{-5}$ at $25^{\circ} \mathrm{C}$ in the first 9-inch surface layer to 478 in the 27-36 inch layer. The mean specific conductance for the 3 -foot soil layer was 331 mhos $\times$ $10^{-5}$ at $25^{\circ} \mathrm{C}$.

Covariance statistical analyses were made to find whether the salt content of the first 9-inch soil layer, or the salts in the cane juices expressed by specific conductance values, had significant effects on the yields of cane. Results obtained were not significant.

The high magnesium content (41 p.p.m. in normal flow and 26 in flood) of the waters from Río Loco (table 5) which flow through a serpentine region, may have been a cause for masking the effect of the gypsum and the sulphur added to the salty land for reclamation purposes. Low magnesium waters, like those from Río Yauco (9 p.p.m.) and the other sources, are not available now for irrigation in Lajas valley. These good and abundant fresh waters will be the main source. for irrigation of the Lajas valley. The high magnesium waters of Río Loco will also be used but provision should be taken to dilute them with the new supplies of fresh waters when the salty lands are to be reclaimed with chemicals.

\section{SUMMARY}

There are about 5,000 acres of high salty Aguirre clay in Lajas valley, in southwestern Puerto Rico, that need reclamation to be fit for crop growth. A field experiment was carried there including four treatments: check, leached, sulphur, and gypsum. The leached treatment consisted of preliminary washings with water. The irrigation source was the same used successfully in the good adjacent sugar cane fields for many years. The crops planted were rice and then, sugar cane. 
Data reported here include yields of rice in terms of whole plant and seed and of sugar cane in terms of tonnage and sugar content as well as conductivity values of the cane juices. Data are also reported for the $\mathrm{pH}$ and the specific conductance values for soil samples taken after the cane was harvested. Chemical analyses of the water supplies are also presented.

No significant results in crop yields due to treatments were obtained. Covariance statistical analyses were made to find whether the salt content of the first 9-inch soil layer, or the salts in the cane juices had significant. effects on the yields of cane. Results obtained were not significant.

Reclamation of salty Aguirre clay with sulphur and gypsum was not succesful: It was found that the irrigation water used was high in magnesium salt. These high magnesium waters might be a cause for the negative results.

\section{LITERATURE CITED}

1. Bonnet, J. A. Laboratory and field studies in an alkaline earth solonchak area of Puerto Rico to be irrigated. Soil Se. Soc. of America. Proc. 1946 (11) : 480-483.

2. Bonnet, J. A. Soil Studies in Lajas valley (Jul. 1945-Aug. 1947). Bul. 86 Univ. P. R., Agric. Expt. Sta. 68 p., Aug. 1950.

3. Department of Agriculture and Commerce. Bureau of Commerce, Annual Book on Statisties of Puerto Rico. Fiscal year 1947-48. Table 127, p. 276, tables $157,158,159$, p. 291.

4. Nelson, L. B. and Muckenhirn, R. J. Field percolation rates of four Wisconsin soils having different drainage characteristics. J. Am. Soc. Agron. 33 (11): 1028-1036, 1941. 